\title{
A critical review of Asia' s emerging middle class be of benefits to the UK tourism and hospitality industry
}

\author{
Liu Yunyao ${ }^{1,}$, , Sun Xiaotong ${ }^{2}$ and Wang Rui ${ }^{1}$ \\ ${ }^{1}$ Sichuan University of Media And Communication. China. \\ ${ }^{2}$ Shandong Institute Of Commerce And Technology. China \\ a18321569369@163.com
}

Key words: Asia's middle class, UK tourism and hospitality industry, Benefits.

\begin{abstract}
Recently, Asia economy is developing and the middle class in Asia is emerging rapidly. With the changes of psychographic, ambition and life style, Asia's middle class attempt to seek for overseas travelling experiences that differ from the past whilst their demands change constantly[18]. Under such a condition, there's a growing of outbound tourism demand trend. As a dynamic phenomenon, anticipating to the trend is a good opportunity for the development of the UK tourism and hospitality industry. The purpose of this essay is to discuss will Asia's emerging middle class be of benefits to the UK tourism and hospitality industry. To begin with, a brief introduction about Asia middle class be given and an analysis about the impact of the increase in Asia middle class will be evaluated. Then there will be a focus on critically analyzing what benefits of Asia's middle class bring to the UK tourism and hospitality industry. At the same time, there will be some analysis about is the emerging Asia's middle class a good opportunity to the UK. Finally, a conclusion will be drawn.
\end{abstract}

\section{Introduction}

From the 1960s, Asia's economy began to grow rapidly, which can be expained in an international comparative context[15]. The rapid economic developed can be reflect on the high growth of income in East Asia, which is a significant reason causing the large growth of Asia's emerging middle class[6]. The boom in Asia's tourism can be recognised as s result of the increase of Asia's middle class. Asia's middle class will become one of the main drivers of the global tourism in the next coming decades[4]. And Dyck said Asia's middle class is one of the fastest growing population groups around the world[7]. There are many reasons for the increase of Asia's middle class, but the faster population growth and the annual per capita income growth in Asia are the most two important reasons of why Asia' middle classes are raising more quickly than other regions [1].

Otherwise, because of the economic development, the food problem of Asia was almost solved and Asia counties gained relative high status and the respect from international. In addition, according to Maslow's Hierarchy of Needs, if the needs which are physiological, safety, social and esteem are satisfied, people may still expect a new discontent and need self-actualization [22]. Traveling can be recognised as a way which may help people achieve their self-actualization. Therefore, self-actualization is the internal element for Asia middle class traveling abroad. There are lots of categorizes of travel, such as holiday travel, business travel, education travel, cultural travel, and so on. Many aspects of Europe countries are quite different with Asia's, such as economy, politic, culture, education, and so on. Therefore, understanding these differences may be the motivation of traveling for the Asia middle class in order to achieve self-actualization.

The growing middle class will bring a lot benefits to Asian and the world. First of all, for some Asia' middle class, they have more disposable time and money, so they are more eager to go to other countries to learn advanced knowledge or experience different culture. This trend will drive the global education tourism and cultural tourism. UK is the main market for Asian students, especially for Chinese and India students. The growth demand of education tourism and cultural tourism 
brings a huge economic benefit to the UK. Secondly, the emergence of Asia's middle class can impact on global consumer market, especially the luxury market. Take China for example, it is a country of consumption and it ranked the first in the purchase of luxury around the world. There are $25 \%$ of the world's luxury goods are purchased by the Chinese and this trend will continue to increase[3]. London as the third most popular shopping destination in the world for Asian, more and more people in Asia like to choose London for shopping. The growing Asia middle class will continue to increase the demand of consumer market in the UK and then bring a considerable profit to the UK retail market. At last, with Asia's economic developing and the increasing of the demand of travelling, it requires Asia's tourism and hospitality industry to expand market. As Asia's middle class, some of them have a certain amount of assets, so there is an increase of Asian tourism and hospitality market to learn advanced Western management experience and buy in existing hotel brands. For the UK, this phenomenon is both an opportunity and a challenge.

The travel of Asia middle class to the UK can be divided in to several main types, such as education tourism, retail tourism or shopping, and heritage tourism. All of these kinds of tourism can be recognised as the opportunities for the tourism industry of UK since these activities may raise the tourism income, which can promote the economic growth of UK.

\section{Education tourism}

Recently, with the emerging of Asia's middle class, students from Asia are more likely to travel and study abroad in the UK. Those overseas students choose the UK education tourism can boost tourist industries and increase tourism profit in the UK. Kelly and McLellan said that overseas student market is a very important one for all businesses, particularly those in the hospitality and tourism area[9]. Compare with other domestic students, students from overseas source markets are more likely to choose visit and sightsee destinations and attractions during their study time in the UK [10]. Take Manchester for an example, it has the largest overseas student number in Europe and it is the most favorite university for Chinese students to apply in the UK. According to the statistics, almost all Chinese overseas students who study in Britain have been to Manchester. Some of them find their friends or students who study at the University of Manchester, while others come to Manchester to watch the football game. Besides, parents of the overseas student always visit them which can also help the development of tourism and hospitality industry in the UK. Take Manchester for instance, the British Tourism Framework Review identifies that Manchester created "an extraordinarily successful marketing campaign aimed at engaging students and enhancing their stay whilst they study in the UK, and attracting their families and friends to visit" [5]. In additional, students are both consumers in themselves as well as future opinion formers. Not only will students' family and friends come to visit them while studying, but also they are likely to spread the information of their positive tourism experience to other travellers and return for future visit [16]. Therefore, except for bringing economic benefits for British tourism and hospitality industry, the growth of Asia' middle class can promote all-round development of the local tourism. In a short term, many overseas students would like to choose do a part time work while studying. Voss said that hotel can adopt the tactic of using part-time employees working varied hours [22]. It is a good method of reducing the cost of service for paying overtime fees to the full-time employees, especially in a tourism peak period, arranging for staff to start their work at different times in the day is very effective method of dealing with the high demand of customers [19]. In a long term, these middle class or their children came to Britain to learn English and tourism and hospitality knowledge can help Britain to spread the advanced management system and concept to Asia and even the world.

Although these overseas students have motivation of the education tourism in the UK, they are the one of the important element to improve the tourism industry of UK. Comparing with other types of 
tourism, education tourists may spend much more time in the destination and their consumption may occupy a large part of the total tourism revenue of UK. From this perspective, the boom of Asia middle class will bring benefits to the UK tourism. As studying in the UK may bring lots of benefits to these Asia students and the population and economy of Asia will keep growing in the future, the demand of education tourism of UK will keep increasing no matter in short term or medium term.

However, some of these oversea students hope find a job in the UK, and even immigrate in the UK after graduation. These activities may increase the expenditure of the UK government, which may put a hard pressure on the government's shoulder. Actually, for these immigration overseas students, they have to face with lots of difficulties, such as pressure on jobs or public service. This phenomenon may bring some unstable factors to the UK society, which may bring negative impact to the UK.

\section{Retail tourism}

According to the survey by the consumer affairs editor of The Telegraph--James Hall, the UK has become a favourite shopping destination of choice for Asia tourists and London, Edinburgh, Manchester become the favourite cities for them to visit. There are two reasons to explain why Britain becomes the third favorite retail tourism country for Asia's middle class. First of all, lower price. The prices of some goods, especially luxury goods, are much lower than Asian's. So more and more Asia's middle class prefer to buy luxury goods in the UK as they can pay less but get better goods. In addition for the factor of low price, exchange rate is also an important reason. Take the RMB (Chinese currency abbreviations) exchange rate against the pound for instance, more and more Chinese middle class choose to come to the UK for shopping because the value of RMB added in recent years[23]. Furthermore, some of the luxury tax is very high in Asian countries which increase the price of some commodities. It means retail prices for luxury goods in China are much higher than identical commodities sold overseas. Therefore, most of Asia's middle class prefer to go shopping in some International metropolis, such as London, Paris and New York.

The trend of retail tourism is of benefit to the UK. A Britain company analyses that compare with other nationalities, such as Americans, Chinese visitors' spend on tax-free shopping in the UK raised by 82 per cent in the year of 2014. Take another statistics for example, London Oxford Street is the most popular tourist attraction which with about 9 million overseas visitors a year. Meanwhile there is a increase in out-of-town places attracts above 3 million tourists per year, such as Bicester Village outlet shopping centre which is the first shopping destination outside London for Japanese visitors. Therefore, it can be said that the biggest benefit of Asia's middle class retail tourism to the $\mathrm{UK}$ is to increase the economic profit. Furthermore, as more and more Asia middle class come to the UK for shopping, it can also increase the hotel occupancy rate which largely contributes to the development of tourism and hospitality industry in the UK[8].

\section{Heritage tourism}

Heritage tourism develops very well in the UK, and UK can be regarded as the global leader in this area of tourism industry[20]. Because of the high reputation, the heritage tourism of UK might be the major destination of Asia middle class tourists. Park stated that "Heritage is a sign and symbol of people's ethnicities, nationalities and identities but subject to different meaning and multiple interpretations. [12]" According to this concept, the Asia tourists aim to understand the characteristics of the UK, which are quite different from there own nations'. Therefore, the proffered of these tourists can be identified, which can help the UK maximise this trend by some marketing strategies, such as advertising and pricing. There is an issue that whether this popularity should be maximize. Once the UK would like to attract more Asia middle class tourists, some problems might be caused. Swarbrooke mentioned that geographical concentration is one of the 
features of UK heritage tourism since heritage tourism is relatively concentrated in some specific area of the UK, including London, some historical cities, some place associated with famous people, and world-famous sites ( such as Stonehenge) [20]. If the trend of popularity of heritage tourism is maximized, these areas may suffer from over-use and lose their special atmosphere and sense of place.

In the past 20 years, the heritage tourism in the UK developed rapidly and the attractions has grown substantially. Nowadays, the UK heritage tourism is well developed and it is a leader in this form of tourism in the world. With the global rise in the popularity of heritage tourism, more and more Asia middle classes prefer to choose the UK heritage attractions as destinations. According to the research of Prentice, 25\% overseas leisure visitors seem heritage and culture as the major motivation for their trip to the UK[14]. Why four in ten of Asian middle class are interested in the heritage and culture of the UK? First of all, Britain is a long history county and it is the first capitalist country and the pioneer of the industrial revolution. There is a vast difference between eastern and western in the architectures culture, lifestyle culture and food culture. Besides, the new generation of Asia's middle class is different from the generation of their grandfather, most of them are young and higher educated, so they are more eager to experience the different cultural backgrounds and obtain the new tourism experience. According to survey by Wilson and Boyle, in the UK 28 world heritage attractions list, Stonehenge, Tower of London and Westminster Abbey become the most popular heritage destinations for Asian, especially for people who are between 25 and $35[24]$.

With the increase of Asia middle class are interested in western heritage and culture attractions, the UK faces with both opportunities and Challenges. On the one hand, the growth interest of Asia's middle class to heritage tourism can boost UK local economy. According to the survey by Poria, almost £12.4biilonn is spent by Asian tourists not just at heritage and culture attractions, but also included broader spending 'motivated' by visiting heritage attractions, such as accommodation . It can be said that the trend of the UK heritage tourism for Asia's middle class indeed bring lots of economic benefits to the UK tourism and hospitality industry. [13]

However, on the other hand, the UK tourism and hospitality industry is also facing challenges. First of all, many other European destinations are entering this profitable market which is a great challenge for the UK heritage tourism industry. The European tourist attractions are also very welcomed by Asia's middle class. Besides, the restriction of the British tourist visa has also become a major challenge for the UK tourism industry whereas the EU visa policy is the advantage for other European countries. Because for Asia tourists, it seems more convenience for them who hold the visa of any one of EU member states( except the UK) to travel around most Europe countries. In addition, it may much cheaper for overseas tourists to visit Europe countries than travel in the UK because the euro exchange rate is lower than the pound.

\section{Brands and hotel chains}

With the development of Asian economies, the Asian tourism market is expanding rapidly. Tourism has been one of the major industries for most of Asian countries[4]. Buying in the existing brands and experience is one of the methods to develop the tourism industry in Asia countries. For instance, because of the country's rising economy and growing business and tourism attractions, lots of global hotel chains have been piled into the India hospitality industry[11]. For these Asia countries, there are many benefits of buying in the existing brand. First of all, they can skip the start-up stage. Most of the international hotels own a high level of reputation and mature operation system. This means that the Asia buyers of these international hotels do not need to train staff and promote their bands. Secondly, inheriting its market also can be considered as one benefit since the Asia buyers can reduce the marketing costs. 
In the future, it can be predicted that with the desire of travelling is rising, more and more tourists, regardless of international tourist and domestic tourists, will travel to Asia[21]. Asian tourism industry may face some issues, such as the number of hotels is insufficient and the quality of bedrooms is not up to standard. However, the purchase power of Asian middle class enhanced, some of they begin to expand the overseas market and invest or buy some existing hotel brands.

The Asian tourism market buy in existing brands has both the advantage and disadvantage for the tourism and hospitality industry. From the long-term perspective, it can increase the number of hotel bedrooms which can help tourism industry to solve the problem of lacking of rooms. But in the short-term, if the numbers of room increase too quick within a certain time, it may inevitably lead to the supply of room over the demand, then the hotel room occupancy rate will fall[19].

The trend that Asian tourist market likes to buy in existing hotel brands and chains is a good opportunity for the UK tourism and hospitality industry. Tourism in Asia has been predicted that it could become one of the major drivers in the global economy, which can stimulate economic development in hospitality[4]. The share of the global tourist market of Asia-Pacific countries will increase from 22 per cent to 30 per cent in 2030[2]. For the UK tourism industry, the revenue increase and the creation of job opportunities can be considered as two main benefits. First of all, it can increase the market share of these Britain hotel brands in Asia. Besides, it can let more people know these brands and boost the brands awareness[17].

However, there is an issue that whether the development will be the threat to the UK tourism industry or not. Because of the economic development, more international hotel groups, luxury goods retailers may enter the Asia tourism market which may reduce the retail tourism market and hotel chain demand of the UK tourism industry. On the other hand, the increase of Asia middle class tourist and the development of the tourism in Asia may cause the increase of terrorist threat. For instance, because of the terrorist threat, the US tourism industry has been most affect worldwide.

\section{Conclusion}

In conclusion, given the analysis the benefits of the growth of Asia's middle class in aspect of education tourism, retail tourism and heritage tourism, it would seem that the growing demand can promote all-round development of the UK tourism and hospitality industry. Generally, no matter what kinds of tourism, tourism is an extremely profitable industry in the UK, except for huge economic profits benefits, such as increasing the Britain's GDP and raising the income of local residents, Asia's middle class can also help Britain to spread its advanced management system and concept back to Asia.

However, through the above analyses, it can be said that the emerging Asia's middle class be of benefits to the UK tourism and hospitality industry, further consideration shows that it also has some disadvantages and challenges. Firstly, some heritage attractions destinations depend heavily on travel expenditures by foreigner tourists as a main source of income. The development of tourism at these regions is seemed as a strategy to promote commerce through exporting goods and services, but the economic and social issues may be caused by a recession in tourism industry could be great[22]. Secondly, tourists may litter in tourism attractions which will cause environmental damage. Consequently, it negatively will increase pollution to disturb local residents, and even worse, it also may discourage tourists from further entering the destinations again. Therefore, it can be said that over the coming decades Asia's emerging middle class will bring both opportunity and challenge to the UK tourism and hospitality industry and know how to grasp the opportunity will be a problem in the future. 


\section{References}

[1]Abhijit. B, Duflo. E. What is Middle Class about the Middle Classes Around the World? Journal of Economic Perspectives, Vol. 22, No. 2, Spring 2008, pp. 3-28. 2008

[2] Information on www.brunei-online.com

[4]Birdsall. N., Graham. C\& Petinato, S. Stuck in Tunnel: Is Globalization Muddling the Middle?

Brookings Institution, Washington, DC, USA. 2000

[5] Information on www.asiamarketresearch.com

[6] Information on www.tourismreview.co.uk

[7]Dyck. S., Hansaku. S, Saxen. R. Emerging Asia's middle class. Deutsche Bank Research, Germany. 2009

[8] Information on www.dbresearch.com

[9]Hurst. J., Niehm. L, Littrell, M. Retail service dynamics in a rural tourism community: Implications for customer relationship management. Managing Service Quality, Vol. 19. No.5, pp.511 - 540. 2009

[10]Kelly. U, McLellan. D. The Impact of Universities on the UK Economy. 4th Report. Universities UK, Strathclyd, UK. 2009

[11]Maggi. R, Padurean. L. Higher tourism education in English - where and why. Tourism Review, Vol. 64. No.1, pp.48 - 58. 2009

[12] Information on www.asiasential.com

[13]Park. H, Y.Heritage Tourism: Emotional Journey into Nationhood. Annals of Tourism Research. Vol. 37, No. 1, pp. $116-153.2008$

[14]Poria. Y., Airey D, Butler, R. Challenging the present approach to heritage tourism: Is tourism to heritage places heritage tourism?, Tourism Review, Vol. 56. No. 1/2, pp.51 - 53. 2001

[15]Prentice. R. Tourism and heritage attractions. Routledge,London, UK. 1993

[16] Information on www.cid.harvard.com

[17]Roppolo. S. The Impact on Tourism as we Educate for a Global Society. Tourism and Culture: Towards the 21 st Century Conference Proceedings. Northumbria University, Newcastle. UK. 1996

[18]Rettie. R.,Hilliar,S, Alpert, F. Pioneer brand advantage with UK consumers. European Journal of Marketing, Vol. 36, No, 7/8, pp895 - 911.2002

[19]Stephen. P.Tourism Management: Managing for Changes. Butterworth- Heinemann, Oxford, UK. 2003

[20]Slack.N.,Chambers.S.,Johnston.R.,Betts.A. Operation and Process Management—Principle and practice for strategic impact.2nd Edition. Prentice Hall. Ediburgh Gate. England.2009

[21] Information on www.insights.org.uk

[22]Thomas.D.C.Domain and development of cultural intelligence: The importance of mindfulness. Group and Organization Management, Nol. 31, No. 1, pp78-99. 2006

[23]Voss. C.,Armistead. C., Johnston. B, Morris. B. Operations Management in Service Industries and the Public Sector. John Wiley and Sons. Chichester. UK. 1985

[24]Wu. F., Heng.T,. Siaw.T., Wee. K, Kiat. T. Potential of the Chinese (PRC) and Indian tourism markets for Asean. Asia Pacific Journal of Tourism Research. Vol. 7, No. 2.pp 45-76. 2002

[25]Wilson. L., Boyle. B. Interorganisational collaboration at UK World Heritage Sites. Leadership \& Organization Development Journal, Vol. 27, No. 6, pp501 - 523. 2006 